\title{
GEORGES VALOIS O LA IN-COHERENCIA DE UN IN-CONFORMISTA. \\ UN VIRAJE HACIA EL FASCISMO (1880-1925)
}

\section{Georges Valois or the in/coherence of a non/conformist. A turn to fascism (1880-1925)}

\author{
JOAN PUBILL BRUGUÉS \\ Universitat Autònoma de Barcelona \\ Joan.pubill@uab.cat
}

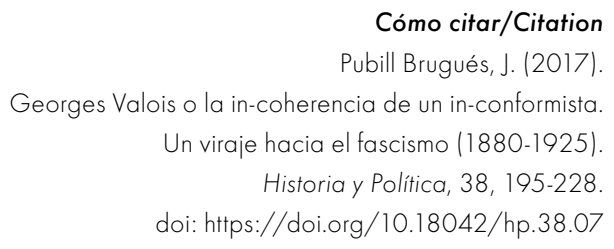

(Recepción: 26/07/2016. Evaluación: 28/09/2016. Aceptación: 30/11/2016. Publicación: 10/11/2017)

\section{Resumen}

El objetivo de este artículo es analizar la relación existente entre la crisis finisecular y el nacimiento de la experiencia fascista en Francia teniendo en cuenta el caso de Georges Valois, cuyo recelo contra el orden liberal decimonónico es paradigmático. Con el objetivo de entender el proceso de fascistización nacido de la desidia contra la Tercera República, el estudio pone en relación el marco cultural y las concepciones nacionalistas resultantes de la derrota de Sedan. A su vez, todos estos elementos se conectan con la biografía intelectual de Georges Valois a partir de un enfoque interdisciplinar. Por esta razón, se ha utilizado un análisis de largo recorrido que considere las coyunturas y los cambios generacionales para comprender cómo de porosas eran las culturas políticas y cómo el fascismo surgió del campo de la contrarrevolución. 


\title{
Palabras clave
}

Georges Valois; fascistización; contrarrevolución; crisis finisecular; fascismo.

\begin{abstract}
The aim of this paper is to examine the relationship between the fin-de-siècle crisis and the birth of the Fascist experience in France taking into account the case of Georges Valois, whose discontent at the liberal order built in the 19th Century serves as a model. In order to understand the process of fascistization as the result of the revolt against the Third Republic, the work puts together the cultural framework and the national conceptions that emerged after the Sedan's default. At the same time, all of these issues are connected by an interdisciplinary approach to the intellectual biography of Georges Valois. For this reason, a long term analysis that considers conjunctions as well as generations shifts has been used to a better comprehension of how mutable the political cultures were and how fascism emerged from the counterrevolutionary political space.
\end{abstract}

\section{Keywords}

Georges Valois; fascistization; counterrevolution; fin-de-siècle crisis; fascism. 
I. INTRODUCCIÓN AL PERSONAJE. LA CONTINGENCIA HISTÓRICA EN GEORGES VALOIS. II. FORMACIÓN DE JUVENTUD Y CONCIENCIACIÓN POLIITICA (1880-1906). III. SE CONSOLIDA EL VIRAJE: NACE GEORGES VALOIS (1906-1919). IV. DESPUÉS DE LAS TRINCHERAS: DE LA MADURACIÓN A LA ESCISIÓN (1919-1925). V. REFLEXIONES ABIERTAS. QUÉ OFRECE VALOIS AL ESTUDIO DEL FASCISMO. BIBLIOGRAFÍA.

\section{INTRODUCCIÓN AL PERSONAJE. LA CONTINGENCIA HISTÓRICA EN GEORGES VALOIS}

La figura de Alfred-Georges Gressent (1878-1945), más conocido como Georges Valois, es digna de atención. Pese al rol que desempeñó en la historia del fascismo en Francia, su trascendencia, recientemente replanteada ${ }^{1}$, es menor de la que cabría esperar de quien fue el fundador de Le Faisceau, el primer partido fascista en suelo francés en una fecha tan temprana como el 11 de noviembre de 1925. Las razones de la disolución del partido en 1928 se pueden situar en 1926, cuando graves problemas de carácter endógeno, como las discusiones acerca de la idoneidad de acoger tránsfugas comunistas, como el exalcalde del Périgueax, Marcel Émile Delagrange, y la escisión del mayor acreedor, el perfumista François Coty, convergieron con dificultades exógenas: la concurrencia por un mismo electorado con formaciones similares y la victoria conservadora de Raymond Poincaré en los comicios de 1926. Este fracaso a la hora de articular un partido de masas fascista lo llevaría a reconsiderar sus posturas anarcosindicalistas. En junio de 1928 impulsó, junto con antiguos miembros de Le Faisceau como Jacques Arthuys, un efímero Parti Républicain Syndicaliste. De nuevo en la izquierda política, su trayectoria acabó en la Résistence. Fue capturado y deportado al campo de concentración nazi en Bergen-Belsen, donde moriría en febrero de 1945.

Todas estas circunstancias, que se pueden comprender como fracasos en lo político y mala suerte en lo personal, junto con lo trágico de su muerte, sirven para explicar la amnesia sobre un personaje con una trayectoria tan

1 Nos referimos a los estudios reunidos en Dard (2011), donde se examina tanto el influjo que tuvo Valois en Francia como el impacto fuera del Hexágono. También al pequeño estudio biográfico hecho por Valla (2003), cuyo trabajo monográfico ahonda en los ańos formativos del personaje hasta la Gran Guerra. 
zigzagueante. Sin embargo, como ha puntualizado Allen Douglas ${ }^{2}$, pese a sus idas y venidas, nunca rompió con su identidad política, cimentada en un socialismo utópico más vinculado a nociones tecnocráticas que con una creencia mesiánica en la clase obrera. Es, precisamente, la adopción de unos valores inmutables, pero adaptados a las circunstancias, lo que convierte a Georges Valois en un caso tan interesante de gestación de un fascista. Una oportunidad para analizar uno de los factores que caracterizaron la crisis europea de los primeros treinta años del siglo xx: la circulación de personajes relevantes por diversas culturas políticas, en ocasiones de signo contradictorio, sin que por ello pueda hablarse exactamente de mero transformismo, conversiones mercenarias o adaptación oportunista a las condiciones de una mejor promoción personal. Por el contrario, tales cambios podían contemplarse por estos individuos - y así ha de considerarse en el análisis del historiador-, como esfuerzos permanentes por encontrar un camino en busca de una identificación política e ideológica, que sufriría las oscilaciones de un periodo de radicalización, compromisos militantes muy exigentes y diversas proporciones de ruptura con el orden existente.

Las siguientes páginas trataran de proporcionar explicación a una de esas vidas ejemplares. Se pretende hacer de la peripecia política de Georges Valois un espacio hermenéutico que nos permita entender, más allá de su propia evolución, la sustancia de un periodo de crisis, del que su drama personal nos proporciona algunas claves fundamentales ${ }^{3}$. El periodo elegido es el que concluye en la formación de Le Faisceau (1925), momento en el que la biografía política de Valois alcanzó un aspecto de consumación, de plena congruencia con una carrera que le convertiría en el primer líder del fascismo francés. Siendo de menor entidad y repercusión los ańos posteriores, parece adecuado centrarse en aquella etapa en la que Valois fue verdaderamente representativo, ya como cuadro «social» de Action Française (AF), ya como crítico feroz de las reticencias de Maurras, ya como fundador de una vanguardia política que pretendía establecer en Francia los fundamentos organizativos, ideológicos y estratégicos de un partido fascista.

Sin embargo, no deben olvidarse los años primerizos. Lo que acabó con una escisión-expulsión de la AF empezó con una trayectoria militante en el campo de la izquierda: un anarquismo heterodoxo cuyos valores se asemejarían a los de un anarquista de derechas ${ }^{4}$. Por este motivo, a través de una aproximación a su trayectoria intelectual, se busca dar sentido a un itinerario que

\footnotetext{
Douglas (1992): 161-162.

Burdiel (2014).

4 Ory (1985); Richard (1988): 65.
} 
resulta peculiar, pero no por ello anormal. Usando a Valois como punto de referencia, el presente trabajo busca poner de relieve diferentes aspectos, a veces desatendidos en el análisis histórico, tanto de método como de enfoque, que ayuden a una mayor comprensión sobre la compleja formación de la experiencia fascista europea. En primer lugar, que las trayectorias políticas que se catalogan como inconformistas tienden a ser un trompe l'oeil, un espejismo. Por otro lado, que el fascismo no se entiende solamente como el resultado de una experiencia bélica, sino como una respuesta, por parte de determinadas culturas políticas antiliberales, a la crisis del progreso ${ }^{5}$. Por último, la importancia de examinar los individuos en su justo contexto histórico. Esta perspectiva implica comprender la biografía intelectual como el método más idóneo para diseccionar las sinergias históricas —en este caso los condicionantes que llevaron a la fascistización de Valois-. A su vez, sirve para poner de relieve los incesantes intercambios y préstamos culturales que existieron entre coetáneos y que han convertido el fascismo en un objeto de estudio tan poliédrico.

\section{FORMACIÓN DE JUVENTUD Y CONCIENCIACIÓN POLIITICA (1880-1906)}

Jean-Claude Drouin ha dicho de Georges Valois que no es un desconocido, sino más bien un mal conocido ${ }^{6}$. Y ello es debido a su trayectoria política aparentemente inconsistente, pero coherente en el fin último que perseguir: buscar una alternativa al sistema liberal-parlamentario republicano. Quienes quieren adentrarse en la vida intelectual de Valois tienen la suerte de disponer de una abundante producción escrita que incluye D'un siècle à l'autre (1921) y L'homme contre l'argent (1928). Se trata de dos libros de memorias no carentes de justificaciones a posteriori y de algunas deducciones teleológicas, que sirven de hilo conductor para desovillar, en los nudos coyunturales, la toma de decisiones que parecen convertirlo en un inconformista, en un incoherente, o en ambos casos a la vez. A través de la experiencia personal, Valois se revela como hijo de la crisis finisecular y de la tumultuosa modernidad.

Alfred-Georges Gressent nació en el seno de una familia trabajadora. Criado por sus abuelos, su primera toma de consciencia fue el republicanismo gambettiano de su abuelo, con el cual se sintió identificado una vez pisó la Exposición Universal de 1889. En sus recuerdos, destaca la percepción maravillada que pudieron tener tantos contemporáneos al visitar los pabellones y

Angenot (1989): 7-13; Taguieff (2007).

6 Drouin (1995): 103. 
extasiarse ante los avances tecnológicos. Su impresión fue que el progreso y la república iban de la mano ${ }^{7}$. Con solo diez años, la influencia de su abuelo le hizo blandir la bandera republicana frente al boulangismo, lo que le mereció algunas antipatías y discriminaciones en la escuela. Mientras él veía en el movimiento contestatario la esperanza de toda la reacción en coalición, algunos compañeros de clase celebraban lo que podía ser el fin de la ruina pública.

Si bien su primera manifestación política llegaría con la publicación de un artículo en el periódico anarquista Les Temps Nouveaux ${ }^{9}$, dirigido en aquel entonces por Jean Grave, la admiración por el republicanismo de su abuelo, que en más de una ocasión había escandalizado a la familia por su exaltación política, le condujo a una paulatina identificación con el obrero «trabajador». Cabe recalcar dicho adjetivo, porque sus simpatías por los trabajadores no se tradujeron en un amor desinteresado hacia la clase obrera. El modelo de obrero que tenía en mente era diametralmente opuesto a los personajes sombríos de la novela naturalista. Tampoco se asemejaba al boulangista Christophe Thivrier ${ }^{10}$, quien conmocionó la Chambre des députés presentándose con la blusa azul de obrero ${ }^{11}$.

Con diecisiete años, se embarcó hacia Singapur. En los viajes transatlánticos se percató de la superficialidad de la civilización expuesta en la Exposición, otrora fuente de admiración. La estada colonial y el contacto con su jefe Chaumette le abrieron nuevos horizontes mentales. Cayó en la cuenta que los parámetros bajo los cuales había sido educado no servían para medir los esprits libres de los mestizos como su jefe Chaumette ${ }^{12}$. Así, el progreso, el sufragio universal o la república popular que se describían en La Revue Socialiste y el Chambard Socialiste le parecieron entelequias. La revisión de la idea de civilización supuso un giro en sus prioridades: a partir de entonces, la civilización tenía que imponerse al sufragio universal ${ }^{13}$.

La razón de su partida se debió al rechazo que obtuvo de su abuelo cuando le explicó con doce años que quería explorar el mundo científico, sinónimo de humanidad y de progreso. Un año más tarde, volvió a intentarlo, sin suerte ${ }^{14}$.

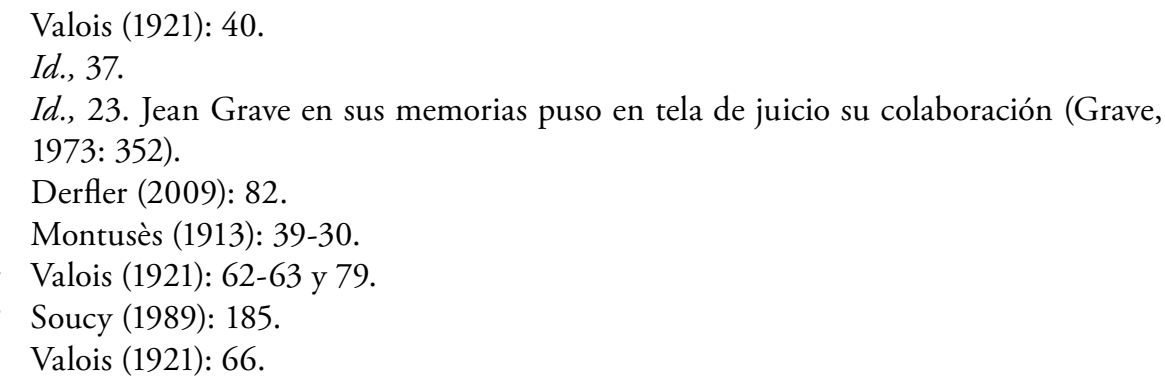


Fue el primer tropiezo con la lógica del dinero. Tras una beca de tres años en un colegio industrial, fábrica de socialistas y anarquistas a su parecer, volvió a la casilla de salida: decidir su futuro. Pero nada había cambiado. Su paso por La France Nouvelle y L'Observateur Français ${ }^{15}$, diarios clericales y reaccionarios -de donde es expulsado junto con otros veteranos por entablar tertulias y discusiones políticas-, y el aprendizaje con un químico conservador le dejaron una impresión negativa de los patronos.

Sobre el químico, diría que era un burgués vil, porque le despidió al pensar que estaba preparando explosivos cuando lo encontró en el laboratorio trabajando. Su empleo terminaría con el despido y la amenaza de denunciarlo a la policía ${ }^{16}$. Un miedo explicable a raíz del atentado del anarquista Auguste Vaillant. Cuando Vaillant hizo estallar la bomba en la Chambre des députés el 9 de diciembre de 1893, Gressent trabajaba en L'Observateur Français, y observó como sus compañeros no alababan a Vaillant, pero tampoco se entristecían por la suerte de los diputados ${ }^{17}$. Un ejemplo de solidaridad tácita existente entre dos culturas políticas que parecían antitéticas, como son la anarquista y la reaccionaria, pero que compartían un vínculo muy fuerte: el desprecio hacia el parlamentarismo liberal-burgués, hasta el punto de aparecer como carriles paralelos del antiparlamentarismo político.

Fueron esas circunstancias materiales, un cúmulo de vicisitudes y malos tratos, lo que le terminó empujando hacia el anarquismo. Sin embargo, sus posturas políticas distaban mucho del colectivismo o del cooperativismo. Su anarquismo individualista aborrecía tanto el liberalismo ciudadano republicano como la idea de igualdad y solidaridad interclasista. Otro ejemplo de la heterodoxia en las culturas políticas lo aportó la figura de Jean Dieudonné, conocido como Lucien Dieudonné, cuyos valores humanistas y su rechazo a la propaganda por el hecho fascinaron al joven ${ }^{18}$. En esos ańos, las posturas políticas se tienen que enmarcar en un eje de coordenadas que, por fidelidad a la heterodoxia, no responden a construcciones conceptuales ideal-típicas weberianas. Las distinciones nítidas entre socialista, sindicalista y nihilista resultan prefabricadas y artificiales cuando se aborda la identidad política en un individuo.

En su proceso de concienciación política, Gressent advirtió los límites del republicanismo de su abuelo: su tutor creía en el valor del esfuerzo como

15 Charles Maurras empezó a trabajar en L'Observateur Français en 1887 y llegaría a ser jefe de redacción un año después. Giocanti (2010): 67.

16 Valois (1921): 70.

$17 \quad I d ., 69$.

18 Id., $115-116$. 
mecanismo de ascenso social. Sin embargo, la república no ofrecía las oportunidades para la movilidad que ambos anhelaban. El sistema escolar solamente abría las puertas a una burguesía que amaba la ciencia para enriquecerse. Al darse cuenta de la rentabilidad del progreso, volteó los eslóganes republicanos y abrazó el anarquismo como la única opción que garantizaba la libertad del espíritu ${ }^{19}$. Juan J. Linz observó cómo la inaccesibilidad a estudios superiores fue un rasgo distintivo de los posteriores dirigentes fascistas ${ }^{20}$.

En correspondencia directa con las experiencias vividas, lo que más pesaba en el anarquismo de Gressent era el individualismo aristocrático y no la vertiente colectivista: su anarquismo no era democrático, sino meritocrático $^{21}$. Su abuela, que sería el otro polo de influencia, y con la que acabaría encontrando más afinidad en su madurez política, le repetía que cuando uno se gana la vida por méritos propios, uno vale sin necesidad de otros. Una concepción vital que tenía el esfuerzo individual como epicentro ${ }^{22}$. De acuerdo con esta forma de entender el trabajo, Allen Douglas lo ha situado dentro de una constelación socialista definida por la noción de laboriosidad. Unas características que subrayaría Henri de Man en L'idée socialiste (1935) un cuarto de siglo después ${ }^{23}$.

En líneas generales, su anarquismo era individualista, de corte marcadamente elitista, más propio del pensamiento pequeñoburgués que de las corrientes obreristas, forjado en las malas vivencias laborales y moldeado por su propia idea de cómo debía ser la igualdad social. De hecho, su deriva anarquista respondió a la voluntad de aplicar un verdadero modelo republicano de movilidad social ${ }^{24}$. En un primer estadio de politización, sus posturas se debieron más a un enraizamiento de lo que debía ser el verdadero republicanismo que a un acercamiento a lo que François Richard llamó anarquismo de derechas ${ }^{25}$, pese a la porosa línea que los separaba.

La entrada en L'Art social fue decisiva para su formación. Allí corroboró sus posturas elitistas en un ambiente donde la consciencia política y la estética

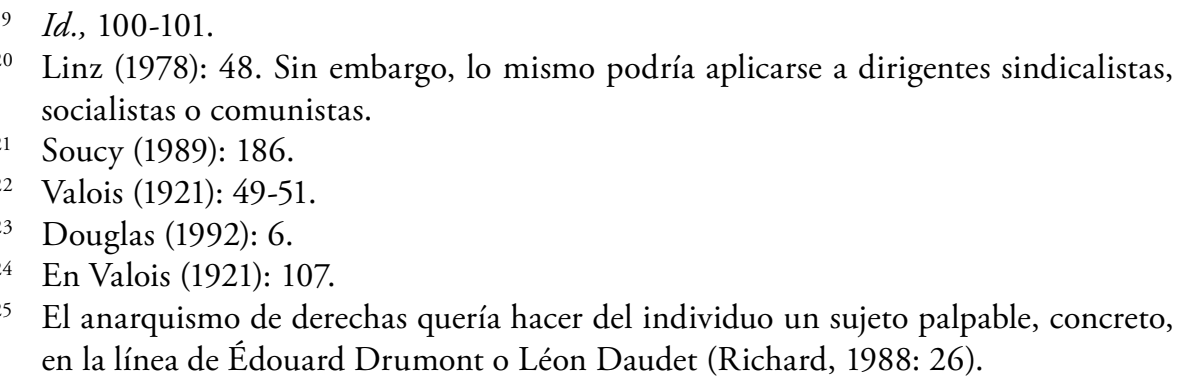


se entremezclaban. La revista mensual, dirigida por Gabriel de la Salle, participaba del ambiente decadentista coetáneo ${ }^{26}$. En definitiva, el círculo de L’Art Social era un lugar donde educar al pueblo y sentirse realizado por ello ${ }^{27}$. Además, le permitió conocer personalidades como Paul de la Salle, secretario adjunto de la Confédération Générale du Travail (CGT) o Agustin Hamon, el cual se lo llevaría a su revista anarcosindicalista L'Humanité Nouvelle, donde conocería a Georges Sorel ${ }^{28}$.

Con este bagaje, encaró el caso Dreyfus, situándose a favor del capitán ultrajado. La coyuntura del proceso reveló lo que el boulangismo había enunciado: la discordancia dentro de las culturas políticas y los matrimonios entre aparentes ideologías incasables. No obstante, el affaire también sirvió como revulsivo para repensar trayectorias personales. En La Petite République, el 9 de agosto de 1896, Jaurès subrayó el impacto que tuvo la toma de postura favorable al capitán en el espacio anarquista debido a su progresivo alejamiento de la acción directa y su acercamiento a organizaciones sindicales y a organismos representativos ${ }^{29}$.

Desde su perspectiva, Gressent veía que la conjunción revolucionaria e institucional, eje de la causa dreyfusard, estaba sujeta a unos limites naturales. Por un lado, había un factor personal: un recelo notorio a los exponentes de la izquierda que procedían de las filas de la burguesía, tales como Édouard Herriot, Léon Blum o el mismo Jaurès ${ }^{30}$. Por el otro, causas de corte político: quedó desalentado en ver cómo líderes exaltados y revolucionarios, una vez en la poltrona institucional, guardaban la revolución en el trastero ${ }^{31}$.

El desengaño que experimentó le hizo replantearse la posición desde la cual implantar un sistema que no impidiese ascender socialmente a aquellos sin rentas pero con talento. El viraje fue más una translación de perspectiva que un cambio radical, el cual se fue fraguando en el curso de los eventos del caso Dreyfus, pero que tuvo, sobre todo, un punto de inflexión durante su experiencia en el regimiento de infantería 46 en la caserna de Fontainebleau en 1900, cuando fue llamado para el servicio militar. Las lecturas de Paul Bourget y Maurice Barrès, junto con la vida en comunidad con sus compañeros de servicio, le hicieron darse cuenta que la disciplina militar permitía al

\footnotetext{
26 Para De la Salle, la decadencia existía en una clase, la burguesa republicana, la cual, ávida de materialidad, no tenía más ideales que en sus apetitos (De la Salle, 1881: 5). Valois (1921): 111. 
hombre ser plenamente dueño de su espíritu ${ }^{32}$. No coartaba al individuo como repetían tozudamente ciertas tribunas obreristas. Como sostuvo Guy Vincent, el servicio militar sobrepasa la dimensión práctica del oficio de las armas porque se convierte en una opción de ascenso social. Además, es en un espacio de aculturación donde el aprendizaje moral se integra dentro de un marco nacional y patriótico, un espacio de disciplina en que los deberes y los derechos aparecen estrictamente delimitados ${ }^{33}$.

La reconsideración de su hermenéutica lo condujo a indagar más hondo en sus creencias, a ir un paso más allá en su cosmovisión. Si había optado por postulados anarquistas porque le parecía que el marxismo, el socialismo y AF eran opciones inapropiadas por falaces y vacías ${ }^{34}$, ahora, tras la entrada de muchos revolucionarios dentro del régimen parlamentario, donde un socialista podía ser mantenido por un adinerado y un burgués presentarse en una lista socialista, abjuró de la farsa de la política. La radicalización que sufrió le aproximó al pensamiento de Friedrich Nietzsche, de quién tomó prestado la idea de la necesidad de un superhombre que se erigiese por encima de la multitud y dejase de bailar al compás de políticos malabaristas ${ }^{35}$.

La culminación del viraje tuvo lugar cuando experimentó la alteridad fuera de Francia. Tras dejar el regimiento, pasó el año nuevo de 1901 en Suiza. Las conversaciones con unos relojeros y un inspector agrario helvéticos le hicieron darse cuenta de la ineficacia de una república porque Francia no tenía los enemigos ni los condicionantes exteriores del país alpino. Además, tuvo consciencia del impacto pernicioso del caso Dreyfus en la nación francesa. Tras su paso por Suiza, se mudó al imperio ruso, donde trabajó como preceptor para una familia acomodada. El impacto que le causó esa tierra a medio camino entre Occidente y Asia le supuso un revulsivo interno: se percató de su condición nacional. Así, el pedido que hizo a París para que le trajesen los libros de Maurice Barrès no se reducía a un simple encargo. Por aquel entonces, el lorenés era el referente de toda una generación porque había sabido vincular una patria física, la tierra, con una tradición heredada, consiguiendo elevar un espíritu francés por encima de intereses personales y egoístas ${ }^{36}$. Gressent no podía haber sido más explícito en resaltar la alteridad que padecía frente a la familia rusa: las hazañas de Napoleón I, ese professeur d'énergie
Id., 149.
Vincent (2004): 85.
Valois (1921): 131.
Id., 151.
36 Burns (1991): 57-58. 
como lo retratan los personajes de Les Déracinés $(1897)^{37}$, le hicieron sentirse parte de un nosotros francés ${ }^{38}$.

De vuelta a París en 1903, empezó a trabajar en la casa editorial Armand Colin. Su condición de padre de familia le cambió la forma de entender las relaciones humanas. Se aisló de sus antiguas amistades obreristas y buscó el afecto en la familia, en aquellos de su sangre que antes había despreciado por tratarse de pequeñoburgueses egoístas. Se acordó de las palabras de su abuela sobre que democracia, socialismo y anarquismo no valían nada si no eran favorables a la familia y al trabajo ${ }^{39}$. La familia era un lugar común para la ultraderecha heredera de la doctrina social de Pierre Guillaume Fréderic Le Play. Charles Maurras oponía el trabajo, la familia y la patria a los valores románticos porque eran capaces de prevenir la anarquía y el individualismo, gérmenes de la revolución y la disolución ${ }^{40}$. Léon Daudet consideraba la familia como el refugio donde el hombre puede cobijarse de las desgracias ${ }^{41}$. En La crise morale (1886), Maurice Pujo aseveró que la familia impedía la caída de la vida interior ${ }^{42}$. Años más tarde, Gressent atacaría la filosofía materialista republicana afirmando que todas las instituciones tenían que ser construidas en base a la familia ${ }^{43}$.

Un año después se haría palpable la mutación introspectiva que vivía desde 1901. El detonante fueron los efectos de la reforma educativa de 1902 emprendida por el Gobierno Waldeck-Rousseau ${ }^{44}$. Gressent se dio cuenta que después de la reforma la ideología anarquista que había profesado se convirtió en la filosofía oficial. Detestaba la participación de personajes mediocres que habían gozado de una buena educación gracias a la fortuna familiar y pretendían dar lecciones morales ${ }^{45}$. Una opinión compartida por el sindicalista revolucionario y antiguo dreyfusard Édouard Berth ${ }^{46}$, quien veía a los intelectuales como una lacra social ${ }^{47}$. Gressent condenó la democracia de los intelectuales

\footnotetext{
Barrès (1911): 232.

Valois (1921): 186.

Id., 198-200.

Mcwilliam (2010): 180.

Renard (2003): 105.

Schiano-Bennis (1999): 574.

Valois (1913): 11-14.

La reforma, promovida por Georges Leygues sacó a relucir la politización que experimentaron muchos profesores durante la mediatización del affaire Dreyfus. Véase: Prost (2008): 47.

45 Valois (1921): 202-203.

46 Berth (1914): 294.

47 Id., 43.
} 
por su hipocresía porque no había en el Panteón democrático sitio para el artesano honrado o el labriego laborioso, quienes mantenían una vida oscura ${ }^{48}$.

En 1904, sumado al reencuentro con sus orígenes familiares y el rechazo a la intelectualidad, Gressent vivió su primera experiencia sindical en Armand Colin, la cual encontró decepcionante. El desenlace de los acontecimientos le condujo a la conclusión que su jefe, Max Leclerc, pese a ser un republicano arquetípico, no era un capitalista reaccionario, sino alguien cuya función era capitanear una empresa para evitar luchas cainitas entre obreros. Gressent quiso trasladar la disciplina, el orden y la jerarquía de Fontainebleau en el plano económico, repudiando la igualdad democrática que se había impuesto en los sindicatos con el dreyfusismo ${ }^{49}$. Sus referentes fueron Pierre-Joseph Proudhon y Georges Sorel. Pese a encontrar poco realista el modelo soreliano, consideraba sus propuestas vitalistas terapéuticas contra la decadencia, en contraste con el socialismo parlamentario, al que consideraba charlatán y ruidoso $^{50}$. Con todo, el sorelismo, como afirmaría años más tarde, sería de enorme importancia ${ }^{51}$. Un ascendente que, sin duda, también reivindicó Mussolini en numerosos escritos ${ }^{52}$.

\section{SE CONSOLIDA EL VIRAJE: NACE GEORGES VALOIS (1906-1919)}

Con veinticinco años, Gressent culminó el proceso reflexión que emprendió en las estepas rusas abrazando abiertamente la religión y la monarquía como opciones verdaderamente opuestas a la Tercera República. La publicación de L'homme qui vient: philosophie de l'autorité (1906), que sería publicado con la ayuda de Charles Maurras por recomendación de Paul Bourget ${ }^{53}$, representa el paso definitivo hacia un nuevo ángulo desde donde atacar la decadencia y la holgazanería: Action Française ${ }^{54}$. La adopción del sobrenombre Valois, en

Valois (1921): 204 y 206.

$I d ., 206$.

Sorel (1910): 160.

51 En 1927 escribiría que los verdaderos orígenes intelectuales y sentimentales del fascismo provenían del socialismo soreliano. Valois (1927a): 6.

52 Por ejemplo, véase la voz «fascismo» de la Enciclopedia Treccani en 1932, escrita por él y Giovanni Gentile, donde pone de soslayo la importancia de figuras como Charles Péguy y Georges Sorel.

53 Valois (1921): 238.

54 En 1927, Valois escribió que entró en AF accidentalmente tras ver representada la Tête d'or (1889, 1894) de Paul Claudel, porque la pieza tenía el valor de no ser 
memoria a la antigua dinastía francesa, explicitó la translación política. La fascinación de Valois por la religión se debió al descubrimiento del infinito, más que al contacto con el Dios cristiano. Un acercamiento al catolicismo que describió como un reencuentro, ya que defendió que nunca había sido anticlerical ni antirreligioso, aseveración que parece dudosa ${ }^{55}$. Un acercamiento a la mística que Alain Besançon definió como moral comuna: una intuición análoga a todas las civilizaciones, las cuales presentan a Dios como un ser inabarcable ${ }^{56}$.

Sin embargo, el encuentro de Valois con lo trascendental no fue una flor en un desierto. Richard Griffiths demostró cómo la generación del cambio de siglo buscó en la religiosidad elementos explicativos alejados del materialismo, el laicismo y el republicanismo ${ }^{57}$. El mismo Valois sería un ejemplo de la influencia que tuvo el nuevo revival finisecular en el pensamiento de alguien que se consideraba anarquista, seis años antes que Henri Massis y Alfred de Tarde publicasen su panfleto Les jeunes gens d'aujourd'hui (1912), atacando los valores de la Tercera República.

En L'Homme qui vient, Valois se esforzó en dar coherencia a un régimen que tuviera como valor más preciado el esfuerzo. Partiendo de esta premisa, criticó sistemáticamente la democracia por asfixiar bajo el yugo del igualitarismo las capacidades innatas de los individuos. A su vez, se mostró igual de feroz con el socialismo porque convertía los obreros en una turba de holgazanes. Sin embargo, sus críticas no se hicieron extensibles ni al anarquismo ni al socialismo revolucionario porque según sus criterios el anarquista era un hombre de orden en busca de penetrar en el mundo de los negocios ${ }^{58}$. En definitiva, el anarquista era un individuo que luchaba para uno mismo y entendía la emancipación del trabajador no como una cuestión de clase, sino como un objetivo personal.

Para Valois, cuando los esclavos se rebelan es porque los aristócratas han fracasado en su tarea de guiarlos. La revolución se convierte en un camino que tiene que abrirse al talento ${ }^{59}$, ya que tiene como objetivo buscar nuevos líderes

monárquica, sino prefascista. En Valois (1927a): XVI-XVII. Esta explicación viene dada tras la ruptura con Maurras y la fundación de Le Faisceau, y contrasta con la versión que da en D’un siècle à l'autre: Valois (1921): 238-243.

55 Valois (1921): 217. Pese a lo que cuenta, un informe policial elaborado en 1897 lo calificaba de ferviente anticlerical. En Soucy (1989): 195.

56 Besançon (2003): 327.

57 Griffiths (1966): 123 y 225. Estudios más recientes han seguido esta línea de investigación: Gugelot (1998).

58 Valois (1906): 101-102.

$59 \quad I d ., 60$. 
que sepan explotar las aptitudes del trabajador. Puso de relieve la importancia de los jefes, junto con el esfuerzo individual, para conseguir una sociedad armónica. Los aristócratas tenían que evitar el modelo hobbesiano de homo homini lupus ${ }^{60}$. Influido por el superhombre aristoi nietzscheano ${ }^{61}$, el joven realista encontró los origines de la civilización en la invención del látigo. Era la autoridad la que impulsó el trabajo, la cultura del esfuerzo: el primer capitalismo ${ }^{62}$. Acorde con este régimen flagelocrático, Douglas arguyó que Valois, lejos de querer reformar el sistema capitalista, lo mistificaba ${ }^{63}$.

En cierta medida, Valois respiraba un air du temps que se remontaba a los inicios del primer socialismo. Se pueden trazar algunos puentes, prudentes, entre lo que planteó el antiguo anarquista y la doctrina sansimoniana. Valois recuperó la alianza histórica de la que habló Saint-Simon en Du système industriel (1821), la cual consistía en el acuerdo entre el monarca y los capitanes de industria, siendo estos últimos jefes naturales y permanentes del pueblo ${ }^{64}$. Sin embargo, la burguesía había perdido su rol histórico encomendado ${ }^{65}$, de ahí que se necesitara establecer un nuevo acuerdo con el monarca para vigorizar de nuevo la energía nacional.

Para ello, el parlamento que ideó no se tiene que confundir con la institución liberal-democrática. Era un espacio de encuentro entre corporaciones, asociaciones económicas y profesionales a partir de una representatividad no proporcional $^{66}$. Un parlamentarismo que mantiene unos ecos con el modelo de corporativismo centralizado sansimoniano, concepto que Franck Yonnet usó para describir el sistema piramidal diseñado por Saint-Simon, donde el Banco de Francia permanecía en la cúspide y se regía por una política interna de corporaciones industriales ${ }^{67}$.

Es importante no olvidar el peso de la cultura socialista no marxista a la hora de presentar una alternativa al liberalismo. El industrialismo sansimoniano era un proyecto que no debe enmarcarse dentro de un marco liberal. Sin embargo, eso no lo convertía mecánicamente en una propuesta obrerista ${ }^{68}$. De ahí que Sortiris Agapitides afirmase que el fascismo, como producto sincrético,

\footnotetext{
Valois (1921): 210-211.

Véase Nietzsche (1995): 81-82.

Valois (1906): 49-54.

Douglas (1992): 12-13.

Saint-Simon (1821): 229 y 206.

Valois (1921): 233.

Valois (1906): 210.

Yonnet (2004): 156 y 165-166.

68 Campillo Iborra (1992): 152-159.
} 
hubiese tomado el sansimonismo corporativista de modelo ${ }^{69}$. Pese a que no se puede tildar Valois de fascista en fechas tan tempranas - ni mucho menos Saint-Simon- parece evidente que en la redacción de L'Homme participó de forma inconsciente del socialismo antiliberal comtiano. Partiendo de esta línea interpretativa y analizando su teoría de la moneda y su concepción del Estado, Alfredo Salsano lo vinculó al pensamiento tecnocrático sansimoniano ${ }^{70}$.

Tras el viraje, Valois puso por escrito que se sintió intelectualmente huérfano. Lo que buscaba era una postura moderna, alistarse con hombres sin apego por un pasado feudal ${ }^{71}$. Durante el tiempo en que Gressent dudaba acerca de por cuál opción inclinarse, salió publicada la Enquête sur la monarchie (1900) de Maurras, la cual se constituyó como acicate para la actualización del monarquismo y punto de apoyo de muchos antirrepublicanos. Para Stéphane Giocanti, Maurras consiguió demostrar que la opción monárquica no era una utopía: puso la cuestión a la orden del día y atrajo adhesiones a la causa ${ }^{72}$.

En el prefacio de la Enquête, Maurras puso de relieve su objetivo de reorganizar Francia bajo un sistema monárquico, el más apto por ser intemporal ${ }^{73}$. No era una propuesta reaccionaria, sino el esbozo de una doctrina contrarrevolucionaria que utilizaba la tradición para excluir de la historia francesa las desviaciones democráticas y socialistas. Como argumentó en L'éducation de Monk (1901), Francia no era un partido, porque la nación era indiscutible y quedaba fuera de toda facción política. Para defenderse de las diatribas que les achacaban métodos revolucionarios, Maurras se defendía arguyendo que ellos trastornaban el significado de revuelta: no dudaban en tergiversar momentáneamente el orden para salvaguardar el bien común ${ }^{74}$.

En su entrevista con Maurras, le explicó su visión de la sociedad y le expuso su modelo de sistema político y de clase. Unos planteamientos que no se podían desligar de su anterior participación en la izquierda. Como explicó al antiguo felibre, lo que buscaba era adaptar a la realidad monárquica sus nociones organizativas socialistas. Como relataría después, el peso de su formación de juventud aún se haría notar pese al viraje. A diferencia de los marxistas, distinguía una clase social de otra económica ${ }^{75}$, con el objetivo de atacar los principios de la alienación del proletariado.

\footnotetext{
69 Agapitides (1937): 101.

70 Salsano (1994): 573-580.

71 Valois (1921): 234-235.

72 Giocanti (2010): 251.

73 Maurras (1925a): 20.

74 Maurras (1925b): 485 y 487.

75 Valois (1921): 245-246.
} 
El ingreso en AF le costó viejas amistades. Tras la publicación de L'Homme qui vient, el periódico socialista Les Temps Nouveaux — donde supuestamente publicó de joven- afirmaría con sorna que Valois dejó de ser anarquista para convertirse en el bufón del Maître Maurras ${ }^{76}$. Influido por la Enquête, el acólito utilizaría el mismo modelo de encuestas para desarrollar tres años después su propuesta de régimen social en La monarchie et la clase ouvrière (1909). Prueba de la influencia maurrassiana es el hecho que las diatribas que lanzó ya no tuvieron como único objetivo el socialismo, la democracia republicana o la burguesía decadente, sino que se hicieron extensibles a los judíos, los francmasones y los protestantes, los quatre états confédérés que Maurras tildaba de colectivos disolventes para la nación francesa ${ }^{77}$. Una de las razones de su escrito era devolver a la burguesía su misión histórica, aplicando las tesis sorelianas de la energía mediante el sindicalismo revolucionario ${ }^{78}$.

Robert Soucy vio que la aproximación del joven realista al colectivismo no tenía nada de socialista, pero sí mantenía unos puntos de contacto con posturas izquierdistas, sobre todo en lo referente a la defensa de sindicatos independientes en una coyuntura en la que el corporativismo era un subterfugio para desmantelarlos ${ }^{79}$. Por otra parte, Douglas ha considerado que $L a$ monarchie et la clase ourvière, como sonda para captar la CGT, fue un fracaso, aunque sirvió para convencer a sectores reaccionarios que el movimiento obrero no era inevitablemente republicano, haciendo recapacitar a algunos sindicalistas acerca de la idoneidad de un sistema monárquico ${ }^{80}$. El mismo Valois reconocería que, pese a haber formulado una buena crítica a la democracia mediante una propuesta sindicalista, fracasaba en el aspecto constructivo porque se estancaba en el sindicalismo inorgánico ${ }^{81}$.

Los años siguientes fueron, para Valois, de acomodación teórica entre los principios de sus dos grandes maestros: Maurras y Sorel. Si la etapa como anarquista fue de formación humana, con el aprendizaje de unos valores, las décadas en AF corresponden a las de su maduración política. El primer maridaje entre maurrassismo y sorelismo se materializó en La Cité Française (1910), donde se agruparon Georges Sorel, Édouard Berth, Pierre Gilbert y Jean Variot. El proyecto de revista que quiso impulsar no consiguió ver la luz debido

\footnotetext{
76 Grave (1907): 6.

77 «De la liberté suisse à l'unité française» (1906). Reimpreso en Maurras (1926): 216-221.

78 Valois (1924a): 297.

79 Soucy (1989): 216.

80 Douglas (1992): 22.

81 Valois (1921): 250.
} 
a malentendidos con Variot ${ }^{82}$. No obstante, la implosión de La Cité Française dio lugar a dos revistas que transcurrieron en paralelo y llegarían a tener un cierto ascendente en la opinión pública: Sorel y Variot trabajarían en la revista bimensual L'Indépendance (1911-1913), mientras que Gilbert y Valois estrecharían su colaboración en La Revue Critique (1908-1914), matriz de lo que sería más tarde el Cercle Proudhon (1911-1914).

Para entender esa voluntad de confluencia, se tienen que rastrear los acontecimientos que tuvieron lugar en 1908 y que marcaron tanto al monarquista como al sindicalista revolucionario. Un fenómeno, el de confluencia entre culturas políticas de la izquierda y de la derecha, que tuvo un gran ascendente en Italia, gracias a la influencia del sorelismo y los vínculos con los maximalistas y sindicalistas revolucionarios italianos, sobre todo con los contactos entre Arturo Labriola con el nacionalista Enrico Corrradini ${ }^{83}$.

Entre 1908 y 1911, Maurras consiguió que AF ganase la hegemonía del espacio católico tras la condena papal de la otra plataforma rival, Le Sillon ${ }^{84}$. En cuanto a Sorel, en esos años puso todo su empeño en atraer a antiguos dreyfusistas descontentos como él del cariz que tomó el caso con la acomodación a la vida pública de sectores obreros. Michel Prat definió el viraje que emprendió de paroxismo porque no fue el resultado de un análisis o de una radicalización coherente de sus posturas, sino más bien el fruto de una frustración y una desilusión ${ }^{85}$.

En medio de las nuevas prácticas políticas y del nuevo lenguaje, la République des camarades, como se conoció durante esos ańos la vida parlamentaria, caracterizada por el aumento de dietas, el tuteo entre políticos o la pérdida de independencia individual en nombre de la disciplina del partido, que pasaron a regir la política ${ }^{86}$, exacerbó el sentimiento de descrédito hacia el parlamentarismo y el régimen republicano. El desengaño de Sorel culminaría con los intereses cruzados — que no sobrepuestos ni mezclados- con Maurras: el primero pretendía resquebrajar el sistema político republicano, mientras que el segundo buscaba ganarse el apoyo de los obreros ${ }^{87}$. Otro factor explicativo, más sutil e indirecto del acercamiento de Sorel a AF, viene dado por el hecho que el escritor Bourget adoptó las Réflexions en una obra teatral titulada $\mathrm{La}$

\footnotetext{
82 Las razones de la ruptura se desconocen en exactitud. Según Variot, Sorel quería que fuera él el redactor jefe de la revista. En Valla (2003): 89.

83 Carli (2001): 154-159.

84 Prévotat (2001): 124-125.

85 Prat (1992): 25.

86 Mayeur (1984): 216.

87 Roman (2002): 177.
} 
Barricade (1910). El escritor dio a conocer la obra del sindicalista revolucionario a un público afín a la ultraderecha, presentándolo como un pensador obrerista que defendía la burguesía ${ }^{88}$. Una muestra del dextrismo, término acuñado por Albert Thibaudet para describir la tendencia a girar hacia posturas de derechistas ${ }^{89}$, que explica los virajes de Péguy, Sorel o Valois a la derecha política.

El Cercle Proudhon dio vida en 1919 a unos Cahiers. En él quería homenajear a Proudhon por sus aportaciones en el campo contrarrevolucionario. Recalcó los aspectos tecnocráticos del pensamiento proudhoniano ${ }^{90}$. De esta forma, convirtieron a Proudhon en referente del socialismo sindical porque, tal y como ha observado Georges Navet, en la concepción de la democracia como amalgama de cosmopolitismo, jacobinismo, parlamentarismo, individualismo y capitalismo, no era extraño encontrar en sus obras argumentos para criticar esos elementos ${ }^{91}$.

Durante el tiempo que estuvo inmerso en el Cercle Proudhon, dejó su trabajo en Armand Colin. En 1914 pasó a hacerse cargo de la Nouvelle Livrarie Nationale, editorial de la plataforma maurrassiana. Cuando la guerra estalló, Valois recordaría cómo la mañana del 2 de agosto Francia despertó toda su energía ${ }^{92}$. La llamada a la Union Sacrée de Raymond Poincaré consiguió que AF hiciese un salto adelante participando de la dinámica política. Derivado de su participación en el poder, mientras Daudet perseguía espías y señalaba traidores, Maurras ganaba simpatizantes entre antiguos defensores del capitán Dreyfus de la talla de Marcel Proust o André Gide, o antiguos desdeñosos con el chovinismo como Remy de Gourmont ${ }^{93}$.

La experiencia bélica en Verdún le sirvió para confirmar lo que intuyó en Fontainebleau: que la sociedad civil tenía que asemejarse en actitud a la vida militar. Condecorado con Croix de la Guerre y la Legion d'Honneur, tuvo consciencia que la llamada a filas no solo implicaba el alzamiento de la nación en armas, donde burgueses, obreros y campesinos luchaban codo con codo formando un nuevo orden armónico, sino cómo la guerra permitía escalar en función del mérito ${ }^{94}$. En segundo lugar, el sentido de la propiedad privada le pareció una verdad incuestionable en el campo de batalla porque cada batallón

\footnotetext{
88 Roman (2003): 100-101.

89 Thibaudet (1932): 29-30.

90 Valois (1912): 31.

91 Navet (1992): 54-55.

92 Valois (1921): 264.

93 Winock (2010): 190-191.

94 Valois (1921): 266 y 271.
} 
poseía su trinchera, su ración, su albergue ${ }^{95}$. En esa tierra de nadie, como definió John Keegan el atrincheramiento, lo que era real era la guerra y no la propiedad, la cual se presentaba como algo ficticio donde conquistar un palmo de tierra era una victoria insegura ${ }^{96}$.

En Le Cheval de Troie (1918) plasmó las reflexiones sobre el estaticismo bélico, una forma de organización de la vida y del trabajo mediante las armas ${ }^{97}$. En el texto, trabajó la idea de que en tiempos de paz se necesita un sabio entiéndase un homme providentiel - que rija la economía en pos de la estabilidad $^{98}$. Pero sobre todo, lo que se destaca en la obra es el papel social que se imputa al ejército. El combatiente vio en las fuerzas armadas un organismo que funcionaba mediante un socialismo autoritario". Con esta conclusión, ratificó la inoperancia de la democracia parlamentaria a la hora de cohesionar la nación. En la trinchera imperaba un clima de hermandad jerarquizada, ni facciosa ni partidista, debido al hecho que no había elecciones, fuente de divisiones $^{100}$.

Una vez desmovilizado, sistematizó en L'économie nouvelle (1919) las consideraciones socioeconómicas que maduró durante la guerra. Allí atacaba duramente a la economía del laissez-faire y al marxismo ${ }^{101}$. La guerra había demostrado que ni los parlamentos ni las comisiones eran idóneos para proveer al Estado medios aptos para comunicarse con la economía nacional ${ }^{102}$. A su vez, la economía del individualismo no permitía reintegrar los excombatientes debido a las leyes de la oferta y la demanda. Aplicar los modelos anteriores a la guerra provocaría el más bello desorden imaginable ${ }^{103}$. La solución tenía que pasar por una sociedad armónica, corporativa, funcional y jerarquizada ${ }^{104}$.

El único modelo capaz de conjugar todos esos elementos era el sindicalismo. Un sindicato verdaderamente obrero y desligado de las agrupaciones de fachada dirigidas por patrones y burgueses, el cual tenía que erigirse no como

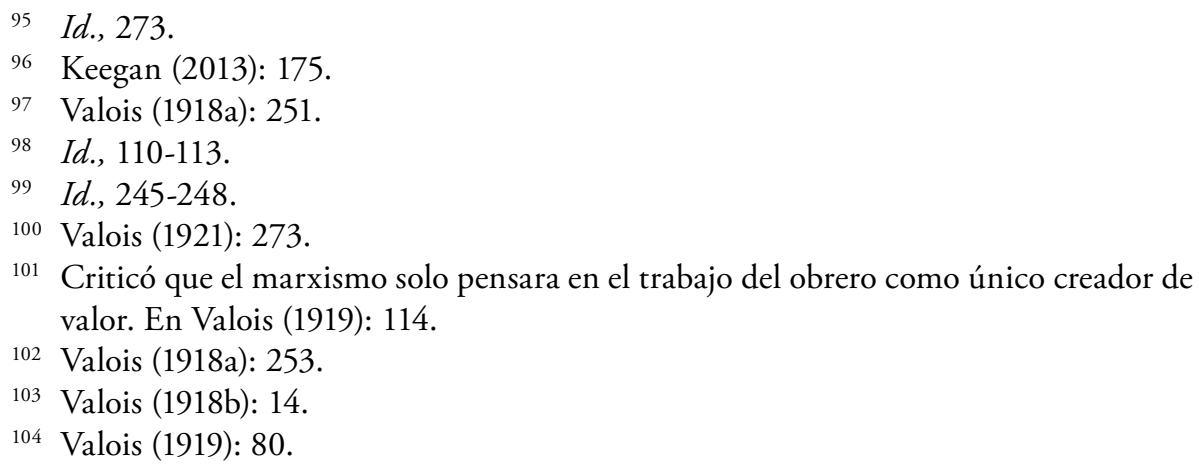


una fuerza anarquista, sino como un agente que garantizara el orden social ${ }^{105}$. Pese a la reivindicación de un autonomismo obrero, Valois continuaba creyendo que eran los jefes de industria y comercio los puntales de la regeneración nacional porque eran quienes tenían que organizar la desmovilización de los excombatientes e incorporarlos en la vida cotidiana. Con esta integración, se abriría una era de prosperidad sin parangón ${ }^{106}$.

Aunque, a grandes rasgos, sus posturas organizativas no habían variado mucho con la paz, lo cierto es que se aprecia un nuevo énfasis en la construcción del orden social. Douglas explicó este matiz afirmando que antes de 1914, Valois estaba más cerca de Sorel, porque su objetivo era organizar los trabajadores sindicalmente como si fuesen parte de un engranaje, mientras que finalizada la guerra, se acercó a los postulados del corporativismo tradicionalista de François René de La Tour du Pin porque puso su empeño en buscar un acuerdo entre corporaciones. La razón del cambio fue el nuevo horizonte de prioridades de AF: con el armisticio, abandonaron la estrategia de ganarse la clase obrera y se aproximaron a los barones de la industria ${ }^{107}$. Una nueva perspectiva que, pese al giro, se enmarcaba en la búsqueda de una tercera vía donde el corporativismo empezó a verse como la solución más plausible en la Europa Occidental, como una nueva revolución ${ }^{108}$.

\section{DESPUÉS DE LAS TRINCHERAS: DE LA MADURACIÓN A LA ESCISIÓN (1919-1925)}

Con la llegada de la paz, Valois observó cómo su generación pasó de ser la heredera de la derrota de Sedan a erigirse como los hombres de la victoria ${ }^{109}$. No obstante, la sensación de decadencia, de abatimiento, no había cesado, como tampoco su obsesión por el dinero, cuya existencia era la tara del siglo que se dejaba atrás ${ }^{10}$. Elogiando a la sangre y al espíritu de haber salvado la civilización de caer en la barbarie, terminaba D'un siècle à l'autre. En los años venideros, Valois volcaría sus esfuerzos en promover una reforma del Estado que pusiese fin a todo lo que simbolizaba la república. Esto daría paso a una serie de desencuentros con Maurras y sus compañeros que terminaría en ruptura.

\footnotetext{
105 Valois (1918b): 41.

106 Id., 9.

107 Douglas (1992): 46.

108 Pasetti (2016): 31-40.

109 Valois (1928): 43.

110 Valois (1921): 293.
} 
Para Yves Guchet, el primer desengaño de Valois fue cuando el Maître no mostró interés en la propuesta de integrar los excombatientes en la vida social que desde 1916 estaba elaborando ${ }^{111}$. No obstante, la ruptura no estaba, ni de lejos, predeterminada. Tras su reingreso, quiso poner en práctica lo que escribió en L'Économie Nouvelle. Para ello, se puso en contacto con el industrial del textil Eugène Mathon, quien admiraba la crítica al marxismo y compartía su parecer acerca de la eficacia del taylorismo a la hora de eliminar la conflictividad laboral ${ }^{112}$. El encuentro con Mathon se produjo un año después que pusiera en marcha diferentes intentonas de sindicato vertical - la Confédération Nationale de la Production (CNP) y su también efímera sucesora Confédération de l'intelligence et de la Production française (CIPF)—, proyectos que no pudieron competir con el sindicato estatal Confédération Génerale de la Production (CGP).

Los proyectos sindicales se desarrollaron en una coyuntura donde se dejó de monetizar la deuda flotante para monetizar el crédito ${ }^{113}$. Valois, cuyos conocimientos en macroeconomía superaban los de microeconomía, postuló la necesidad de disponer de un franco fuerte en La monnaie saine tuera la vie chère (1920). En su reflexión, defendió que el Estado tenía que evitar que la plutocracia, es decir, que los especuladores extranjeros se aprovechasen de la inestabilidad de Francia para empobrecer a los productores, tanto propietarios como trabajadores sin distinción ${ }^{114}$. Una vez que sus argumentos antiinflacionistas y su defensa del patrón oro fuesen aplaudidos en los coloquios de la Semaine de la monnaie organizados por el CIPF, propuso a Maurras promover una campaña a favor de la recuperación de los Estados Generales. Lo que para Valois era una oportunidad para ganar influjo, para el viejo felibre, pese a no tomarse demasiado en serio la propuesta, era una buena maniobra política ${ }^{115}$.

El excombatiente quería erosionar la legitimidad de la república aprovechando la crisis financiera. Su plan pasaba por recuperar una institución orgánica donde la representación fuera mediante cuerpos y no individuos ${ }^{116}$, y eliminar la Chambre después que el gobierno colapsase por no tener el valor de adoptar, por los costes políticos, medidas dictatoriales para hacer frente a la crisis ${ }^{117}$. Además, permitían visibilizar las regiones, centrales en el discurso

\footnotetext{
111 Guchet (1965): 1127-1128.

112 Soucy (1989): 226.

113 Debeir (1980): 631.

114 Valois (1920): 57-58.

115 Douglas (1992): 55.

116 Valois (1927b): 197.

117 Valois (1922): 33.
} 
antijacobino maurrassiano. Durante la campaña, se explotaron las acusaciones que desarrolló en L'État et la production (1922), señalando que el Parlamento era el más grave de los peligros que Francia tenía que afrontar porque era culpable tanto de la situación inflacionista como de no permitir que Alemania pagase las compensaciones de guerra. Por eso concluyó que era necesario eliminar de una vez el parlamentarismo liberal ${ }^{118}$.

No obstante, la campańa no cuajó. Olivier Dard ha señalado que las disensiones entre Etienne Bernard-Précy, director de la revista de negocios Journée industrielle, y los resultados electorales, nada favorables a la liga, fueron las causas principales ${ }^{119}$. Como Eugen Weber extrapoló, cada vez que Valois perfilaba sus ideas y pulía sus proyectos, más enemistades despertaba ${ }^{120}$. A partir de entonces, Valois acarrearía dudas acerca de la estrategia de la dirección. En primer lugar, el asesinato de Marius Plateau, secretario de los Camelots, a manos de la anarquista Germaine Berton quedó sin vengarse ${ }^{121}$. Pese a la retórica del Maître, se planteó si AF no había perdido el ímpetu y la vigorosidad de antaño. En el período de mayor apogeo de la liga, en una coyuntura en que Berth calificó a Maurras de dictateur spirituel ${ }^{122}$, Valois se preguntaba si sus compañeros estaban capacitados para lo que se avecinaba ${ }^{123}$, interrogándose si optarían por adoptar la vía italiana. Con el ejemplo de Italia en mente, no entendía el tacticismo electoral de una plataforma que repudiaba el parlamentarismo. Sin embargo, pese a las reticencias, participó en los comicios legislativos de 1924 debido a la amenaza que suponía una victoria del Cartel des gauches y la llegada al poder del republicano Édouard Herriot. Maurras despejaría tajantemente las dudas sobre la idoneidad de la vía legal en un artículo el 17 de enero de 1926 en el órgano homónimo de la liga, Action Française ${ }^{124}$.

Para entonces, Valois ya había hecho pública su admiración por el Duce. En enero, había ido a Italia junto con Mathon y Bernard-Précy, entre otros,

${ }_{118}$ Id., 68-69 y 70-71.

119 Dard (2008): 149.

120 Weber (1962): 207.

121 Valois (1928): 99.

122 Berth (1924): 243.

123 VALOIS (1928): 57.

124 «Si esta forma de entender las elecciones, compartida por Mussolini, Boulanger, Paul Déroulède y Maurice Barrès es, como dice ingenuamente Valois, una «rutina», no es ni en 1924 ni en 1919 que Action Française la está practicando: es en 1909, hasta en 1908. «Por todos los medios legales», dije por aquel entonces, y esto es de sentido común». Citado en GUCHET (2001): 185. 
para informarse acerca del estado de la Italia fascista, cuatro meses antes de las elecciones. Antes de su viaje a Roma, era consciente de los aires caldeados en AF. La tensión llegó a enturbiar su estancia en la península itálica: la entrevista con Mussolini le valió la ruptura con Mathon. Para Valois, la razón de la ruptura con el industrial fue Désiré Ley, artífice de un complot contra su persona. A posteriori, Valois justificaría la ruptura arguyendo que Mathon era un plutócrata ${ }^{125}$, es decir, un miembro de esos grupos de financieros y políticos que iban a la una para acallar la voz del pueblo y robar a la burguesía productora ${ }^{126}$. En definitiva, acusó a Mathon de ser un «hombre que pagaba ${ }^{127}$.

Una vez de vuelta a París, expuso a sus compañeros su teoría acerca de la necesidad de una revolución en Francia similar a la que se hizo en Fiume. Si el bolchevismo era una revolución hecha en nombre del internacionalismo, el fascismo se hacía en nombre de nación ${ }^{128}$. Esa revolución tenía que servir para que banqueros, productores y ahorradores se organizaran socialmente ${ }^{129}$. La mayor recriminación que le hicieron sus compañeros a su proyecto fue que concibiese al monarca como una figura accesoria y accidental ${ }^{130}$. La decepción de Valois fue mayúscula cuando su propuesta de promover un golpe de Estado simulando la experiencia italiana no obtuvo el apoyo del líder ni del pretendiente Felipe de Orleans ${ }^{131}$. Le reprocharon que concibiese al monarca como una figura accesoria y accidental ${ }^{132}$.

Resulta muy difícil rastrear los intríngulis que propiciaron la ruptura sin entrar en disquisiciones historiográficas que caigan en el mero positivismo. A grandes rasgos, los dos motivos que se han esgrimido para explicar la ruptura vienen dados por razones económicas y por discrepancias doctrinales. En lo que atañe a la ruptura por razones de financiación, Eugen Weber opinó que las fricciones entre Maurras y Valois se produjeron en torno al coste de publicar diariamente o semanalmente Le Nouveau Siècle (1925-1928), el cual tenía que sustituir los Cahiers des États Généreaux $(1923-1925)^{133}$.

\footnotetext{
125 Valois (1922): 10.

126 Valois (1919): 35.

127 Valois (1928): 158 y 143.

128 Valois (1924b): 151-152.

129 Id., 177.

130 Valois (1926): 17.

131 Levey (1973): 283.

132 Valois (1926): 17.

133 Weber (1962): 209.
} 
Por lo que respeta a posibles divergencias ideológicas —idea interesadamente explicitada por Valois tras la ruptura-134, Yves Guchet apuntó que probablemente Maurras temió que una publicación semanal compitiera con el órgano editorial oficial y erosionase su autoridad en materia táctica ${ }^{135}$. Sin embargo, una aproximación a la cultura política de ambos personajes contradice este enfoque: lo que convirtió en incómoda la escisión fue que el excombatiente profesaba el antiliberalismo y la reacción a la democracia como cualquier otro miembro de $\mathrm{AF}^{136}$. Además, había en juego un elemento de primacía: la hegemonía en el discurso de la latinidad ${ }^{137}$. Cualquier emulación o acercamiento a Mussolini supondría la subordinación de Francia a Italia.

Fue el aburguesamiento de la liga lo que condujo a la reacción de Valois ${ }^{138}$. No obstante, la decisión no se explica solamente como una consecuencia reactiva, sino como un salto hacia adelante coherente con la dinámica de maduración en la que había entrado fruto de la divergencia táctica ${ }^{139}$, que a la postre conduciría a Maurras a blandir un discurso aburguesado y al excombatiente a proponer un estado fascista donde la burguesía productora se supeditaría a la labor de los excombatientes ${ }^{140}$. Pese a que Maurras vio una oportunidad para atraerse a la masa de excombatientes mediante Le Nouveau Siècle y la Légion (1925) — siguiendo de la misma estrategia que se empleó una década atrás para captar el proletariado-, la actitud movilizadora y combativa de Valois y Antoine Redier ya no se adaptaba a sus esquemas tácticos ${ }^{141}$.

Este décalage entre inmovilismo y acción culminaría el 11 de noviembre de 1925, cuando se presentó Le Faisceau en la Salle Wagram. Tras la arenga de Philippe Barrès, hijo del autor de Les Déracinés, los chemises bleues de la nueva organización emprendieron una marcha sobre el Arco de Triunfo, con el objetivo de hacer cumplir los votos de los caídos por la patria ${ }^{142}$. El despliegue, que recordaba a la marcha sobre Roma, no gustó a Maurras. Ahí empezó un intercambio de reproches entre el excombatiente y el Maître que agitó la opinión pública francesa e italiana ${ }^{143}$. La escalada de tensión llegó cuando Valois se hizo con el

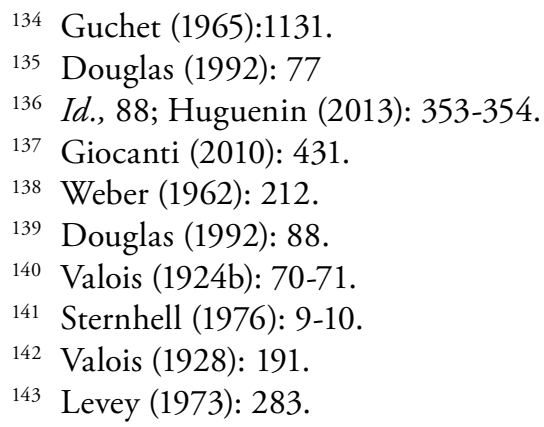


control de la editorial de Action Française y, en consecuencia, los estudiantes de AF boicotearon la reunión de Le Faisceau. A su vez, las camisas azules desmantelaron la sede de la liga hasta que los camelots les expulsaron ${ }^{144}$.

Frente a las divergencias tácticas, la ruptura también se explica mediante la afinidad personal. Las conspiraciones contra Valois fueron comunes dentro de la cúpula: se quiso persuadir a Maurras de que el antiguo héroe de Verdún seguía sus propios intereses ${ }^{145}$. En sus memorias, Valois acusó la sombra inductora de Maurice Pujo ${ }^{146}$. Las adversidades personales ayudan a entender los movimientos entre bambalinas que provocaron que dos trayectorias casi homologables acabasen por colisionar ${ }^{147}$. La muerte de Philippe (1923), hijo de Daudet, agudizó los recelos: Maurice Pujo y Pierre Lecoeur mantuvieron a Valois en el más absoluto de los silencios mientras se investigaban los hechos, ya que tanto su hijo Bernard como él estaban en el punto de mira por sus antecedentes anarquistas. Además, el misterio de la muerte acaeció cuando Valois ponía en marcha la campańa antiparlamentaria y Daudet, por el contrario, pretendía ser reelegido como diputado ${ }^{148}$. Un choque de intereses que, sumado al hecho de las suspicacias y de las habladurías, degradó la amistad y azuzó la animadversión de una relación hasta el momento más que cordial.

En definitiva, la creación de Le Faisceau fue la plasmación de la ruptura que acabaría en una extraña secesión-expulsión. El propósito de la plataforma que acabó por ser un nuevo partido era recuperar las ideas ensayadas en el Cercle Proudhon y terminar con el ensimismamiento de las familias antiliberales. A modo de comparación, el impacto que tuvo Le Faisceau en el campo de la contrarrevolución fue similar al que tuvo AF cinco décadas atrás: fue la reacción de los jóvenes simpatizantes de la derecha frente al nacionalismo burgués $^{149}$. Así, la liga realista sufrió en sus carnes la medicina que había recetado a ligas conservadoras hasta ese momento tan influyentes como la Ligue de la Patrie Française de Jules Lemaître, la cual, pese a ser representativa del nationalisme fermé, fue criticada por ser demasiado mundana y acomodada como para representar una opción alternativa al sistema republicano oportunista ${ }^{150}$.

144 Weber (1962): 210-211.

145 Sérant (1978): 26-27.

146 Valois (1928): 182.

147 Maurice Pujo abrazó el monarquismo en 1903. Los dos militaron en el campo pro Dreyfus, si bien, a diferencia del exanarquista, Pujo no solo se distanció en 1899, sino que abjuró de su postura de juventud.

148 Douglas (1992): 84-86.

149 Sternhell (1976): 8.

150 Winock (2004): 19. 
Dos décadas más tarde, Maurras rememoraría la marcha de Valois con amargura. El resentimiento duraría hasta 1943, cuando el anciano felibre lanzó una última invectiva, ya inútil, a quien fue otrora su compañero ${ }^{151}$. Como contó Valois, «esos señores no han empezado a quejarse del abandono, de la ruptura, de la traición hasta que han sido testigos del éxito de le Faisceau y del Nouveau Siècle» ${ }^{152}$.

\section{REFLEXIONES ABIERTAS. QUÉ OFRECE VALOIS AL ESTUDIO DEL FASCISMO}

La singularidad de la trayectoria política de Valois puede resultar, sorprendentemente, poco singular cuando se han abordado los aspectos biográficos de referentes a su formación política y maduración intelectual. Las trayectorias de los inconformistas tienden a virar, a dar vueltas, pero lo hacen sobre un mismo polo, rotando en torno a un mismo eje. Esa es la característica que los diferencia de los oportunistas, de los simples chaqueteros. Véase, por ejemplo, la sólida trayectoria de Henri Rochefort, quien se sumó a todas las aventuras que le permitiesen atacar al oportunismo republicano ${ }^{153}$. Si bien existen modificaciones en el pragmatismo político de Valois, en general, la aparente incoherencia de su viraje respondió al acomodamiento a una nueva posición que le sirviera para aplicar su modelo y defender sus valores. Las malas experiencias laborales, junto con la actitud de algunos compañeros de su misma clase social, le hicieron ver que el empeño, entendido como el esfuerzo individual, era el último garante del triunfo o del fracaso.

Pese a todo, Valois no era un individuo puro. No lo es en tanto que no existe la pureza en la ideología. Más bien, es todo lo contrario: un ejemplo de la porosidad de las culturas políticas, entendidas más allá de conceptualizaciones abstractas y de un corpus de ideas. La adaptación del hombre en la coyuntura, junto con la defensa de unos valores, explica el comportamiento a primera luz errante del personaje. La pregunta del millón es saber cuándo se hace Valois fascista. Responderla significaría disponer de la llave de uno de los grandes debates de la historia contemporánea: saber cómo y cuándo nace el fascismo. En sus tan conocidas como controvertidas tesis, Sternhell planteó la necesidad de analizar la formación del fascismo con una lente que

\footnotetext{
151 Boutang (1984): 427.

152 Valois (1926): 114.

153 Winock (1993): 85.
} 
situara el punto de partida en la crisis finisecular ${ }^{154}$. A modo de vidas cruzadas, las trayectorias de líderes fascistas como Ramiro Ledesma Ramos, desde su formación vanguardista y clásica hasta su concepción de la revolución nacionalsindicalista ${ }^{155}$, o Benito Mussolini, desde el sansepolcrismo inicial hasta la toma de poder ${ }^{156}$, sacan a relucir la importancia tanto de la formación política primigenia como la importancia de la ideología y de la estética. Cuestiones que deben inserirse en la crisis finisecular y en la porosidad de las culturas políticas.

Pese al rechazo de buena parte de la historiografía francesa a las tesis de Sternhell ${ }^{157}$, parece evidente que la gestación del fascismo respondió a una necesidad de dar respuesta tanto a la crisis del liberalismo como al miedo a la revolución. Si la década de 1880 resultó capital para deshilachar los nudos históricos que aparecen en la formación del fascismo ${ }^{158}$, no es menos cierto que desde la crisis del liberalismo clásico en 1870 las sociedades europeas experimentaron un proceso de larga duración para adecuarse a la modernidad. El «nos parece que somos exiliados en casa de nuestros coetáneos» de los hermanos Goncourt ilustra magníficamente la incomodidad de muchos sectores sociales conservadores que se sentían superados por los cambios y transformaciones acarreadas por el proceso de modernización ${ }^{159}$. De resultas de esa mediocridad y decadencia burguesas que la propuesta de Valois se encaminase a ofrecer un proyecto obrero a toda la burguesía no plutocrática con el fin de dinamizar la nación ${ }^{160}$.

Aunque para Drouin el valoisismo, pese a ser el origen del primer fascismo francés, no pudiera catalogarse de fascista porque nunca tuvo en su agenda política una revolución brutal y violenta como otros fascismos europeos $^{161}$, y para Sternhell fuese un fascisme naïve ${ }^{162}$, el estudio de Valois provee de interesantes materiales para una reflexión transnacional de los orígenes del

154 Sternhell (1978): 406; Sternhell (1995): 20.

155 Gallego (1998): 21-55.

156 Gregor (1979): 44-47; Milza (1987): 170-189 y 261-265.

157 Para la constelación de críticos, véase Winock (1983); Julliard (1989); Berstein (2007), y Berstein y Winock (2014). Para unas aproximaciones más favorables a Zeev Sternhell, véase Dobry (2003), y Jenkins (2007). Un estado de la cuestión de la problemática en Angenot (2011).

158 Sternhell (1983): 20-21.

159 Citado en Prochasson (1994): 60.

160 Valois (1924a): 80.

161 Drouin (1995): 121.

162 Sternhell (1983): 319. 
fascismo. Por ejemplo, resultan de gran interés las liaisons que existieron entre el sindicalismo revolucionario francés y el italiano, donde Valois puede incorporarse y compararse a toda una estela de personajes que, formados en el socialismo, como Sergio Panunzio o Agostino Lanzillo, se convirtieron en cabezas pensantes del fascismo ${ }^{163}$.

En primer lugar, las muchas propuestas de Valois proseguían el objetivo de establecer un sistema político que permitiese integrar el individuo dentro de la sociedad. Primero con su idea de monarquía, donde la suerte del monarca, como Señor de la Paz, era indisoluble de la nación ${ }^{164}$. Después, con su concepción de la nación entendida de un modo tecnocrático como una jerarquía de jefes ${ }^{165}$. Modelos que querían prevenir la pérdida de identidad del individuo, el ocaso de la civilización y el estancamiento social. Temas recurrentes en esa crisis que, desatada por las irregularidades causadas por el progreso y sintomáticas del advenimiento de la modernidad, hicieron replantear la viabilidad del orden liberal. Como Pierre Citti advirtió, esos miedos se convirtieron en un leitmotiv para autores finiseculares como Maurice Barrès, quien a su vez sería una fuente de inspiración para Valois en su madurez ${ }^{166}$.

La segunda reflexión que proponemos es ver el fascismo como un espacio que va más allá de la existencia de un partido. Esto explica las dificultades que tuvo que afrontar Le Faisceau a la hora de captar su clientela debido a la competencia con las Jeunesses Patriotes (1924) de Pierre Taittinger o Les Croix-de-Feu (1927) del coronel François de La Rocque, junto con el impase electoral que supuso la nueva candidatura de Raymond Poincaré como opción conservadora en 1926. La metodología propuesta por Philippe Burrin de abordar el espacio fascista como un campo magnético resultó muy interesante porque puso de relieve la existencia de pasarelas a través de las cuales trayectorias políticas socialistas, republicanas y comunistas desembocaban en el fascismo ${ }^{167}$. Un filón que recientemente ha proseguido Steven Forti en el estudio del transfuguismo de la izquierda al fascismo ${ }^{168}$. Sin embargo, el caso de Georges Valois nos sugiere todo lo contrario: su proceso de fascistización, tuvo lugar cuando militaba activamente dentro de una formación

\footnotetext{
163 Sternhell, Sznaijder y Asheri (1994): 321.

164 Valois (1924a): 311-312.

165 Valois (1924b): 51.

166 Citti (1987): 94. Junto con Sorel, Valois convertiría a Barrès en un referente para su modelo fascista. En Valois (1927a): 6.

167 Burrin (1986).

168 Forti (2014).
} 
ultraderechista, nacionalista integral y contrarrevolucionaria, mucho antes de la llegada de Hitler al poder, pese a su pasado como anarquista sui géneris. Entre la tesis tan repetida de la imprégnation fasciste en la sociedad francesa de entreguerras ${ }^{169}$, y la presentación de $\mathrm{AF}$ como un partido fascista ${ }^{170}$, existe un extenso campo de matices. Pese a desarrollar la procedencia extranjera del fascismo en Francia, René Rémond no pudo dejar de admitir que AF abonó el terreno para que eclosionara ${ }^{171}$. Es en esta brecha donde se tienen que buscar los procesos de creación de un fascista.

En tercer lugar, subrayar que el fascismo, como toda cultura política, se entiende a modo de experiencia individual. Porque el individuo, como expuso Sergio Romano, es un lugar histórico donde se encuentran todas las fuerzas económicas y morales que hacen la historia ${ }^{172}$. Resulta evidente que un análisis que se quiera certero debe considerar tanto la dialéctica intrageneracional e intergeneracional como la mentalidad y lógica propias de la personalidad del individuo. El individuo, como agente histórico activo y pasivo, responde tanto a valores e ideas como al dictamen de lo emocional. Sumado a las divergencias tácticas imputables a los cambios generacionales, el peso de las emociones en la politización no debe menosprociarse ${ }^{173}$. En su dimensión más prosaica, la aparición del primer partido francés abiertamente fascista se debió a la fricción de las relaciones humanas. Un factor explicativo que escapa a análisis tanto materialistas como culturalistas o ideológicos.

Por último, el fascismo francés, en este caso el valoisiano, no debe juzgarse a posteriori. Si algo pone de relieve la suerte de Le Faisceau es que el momento de auge del fascismo ocurrió en los años treinta tras el crac bursátil, cuando consiguió convertirse en un movimiento de masas. Antes de que los fascismos se hicieran con el Estado, existieron fascistas como Valois, análogos cronológicamente a la experiencia italiana por lo que se refiere a la maduración intelectual, pero divergentes en lo que concierne al asalto al poder. Así, el caso italiano resulta ser la excepción y no la norma. Como Ferran Gallego ha puesto de relieve, el fascista aparece como el resultado y no la causa de la fascistización ${ }^{174}$. Una propuesta de análisis que ayuda a entender las sinergias dentro del fascismo, cuyo espacio natural es el de la contrarrevolución. Con esta lógica, se puede hablar, como apuntó Soucy, de oleadas en el proceso de

169 Girardet (1955): 530.

170 Nolte (1969): 82, y Soucy (1989): 16.

171 Remond (1963): 177 y 224.

172 Romano (1981): 97.

173 Spiegel (2006).

174 Véase: Gallego (2014): 29-77. 
fascistización de la sociedad ${ }^{175}$, vinculadas a la búsqueda de una alternativa a la crisis de la modernidad. Alfred-Georges Gressent sería, pues, un exponente de esta primera oleada, incardinada en el convulso clima cultural finisecular y fruto de la primera gran crisis de la modernidad liberal.

\section{Bibliografía}

Agapitides, S. (1936-1937). Saint-Simon et le corporatisme fasciste. Revue d'histoire économique et sociale, 23 (2), 101-109.

Angenot, M. (1989). Malaise dans l'idée de Progrès. Mots, 19 (1), 5-22. Disponible en: https://doi.org/10.3406/mots.1989.1462.

- (2011). L'immunité de la France envers le fascisme: un demi-siècle de polémiques historiénnes. Études françaises, 47 (1), 15-42. Disponible en: https://doi. org/10.7202/1002514ar.

Barrès, M. (1911) [1897]. Les Déracinés. París: Émile-Paul Ed.

Berstein, S. (2007). Pour finir avec un dialogue de sourds. À propos du fascisme français. Vingtième Siècle. Revue d'Histoire, 95, 243-246. Disponible en: https://doi.org/10.3917/ ving.095.0243.

— y Winock, M. (dirs.) (2014). Fascsime français? La controverse. París: CNRS Éditions.

Berth, É. (1914). Les méfaits des intellectuels. París: Marcel Rivière et Cie.

- (1924). Guerre des États ou guerre des classes. París: Marcel Rivière et Cie.

Besançon, A. (2003) [1994]. La imagen prohibida: una historia intelectual de la iconoclasia. Madrid: Ediciones Siruela.

Boutang, P. (1984). Maurras: la destinée et l'oevre. París: Plon.

Burdiel, I. (2014). Historia política y biografía: más allá de las fronteras. Ayer, 93 (1), 47-83.

Burns, M. (1991). Families and Fatherlands: the lost provinces and the case of Captain Dreyfus. En R. Tombs (ed.). Nationhood and Nationalism in France. From boulangism to the Great War, 1889-1918 (pp. 50-63). Londres y Nueva York: Harper Collins.

Burrin, P. (2003) [1986]. La derive fasciste: Doriet, Déat et Bergery, 1933-1945. París: Éditions du Seuil. Disponible en: https://doi.org/10.14375/NP.9782020093576.

Campillo Iborra, N. (1992). Razón y utopía en la sociedad industrial. Un estudio sobre Saint-Simon. Valencia: Servei de Publicacions de la Universitat de València.

Carli, M. (2001). Nazione e rivoluzione. Il «socialismo nazionale» in Italia: mitologia di un discorso rivoluzionario. Milano: Edizioni Unicopli.

Citti, P. (1987). Contre la décadence. Histoire de l'imagination française dans le roman 18901914. París: Presses Universitaires de Paris.

Mientras que la primera oleada se situaría en torno a la victoria del Cartel en 1924, y en donde cabría situar el periplo político de Valois, la segunda oleada llegaría con la fascinación del hitlerismo después del ascenso al poder de NSDAP en Alemania (Soucy, 1995). 
Dard, O. (2008). Les milieux économiques et l'Acton Française. En M. Leymarie y J. Prévotat (eds.). L'Action Française. Culture, société, politique (pp. 141-154). Villeneuve d'Ascq: Presses Universitaires du Septentrion.

- (ed.) (2011). Georges Valois, itinéraire et réception. Berna: Peter Lang. Disponible en: https://doi.org/10.3726/978-3-0352-0053-9.

Davranche, G. (2009). Pelloutier, Pouget, Hamon, Lazare et le retour de l'anarchisme au socialisme (1893-1900). Cahiers d'histoire. Revue d'histoire critique, 110, 139-161.

Debeir, J.-C. (1980). Inflation et stabilisation en France, 1919-1928. Revue économique, 31 (4), 622-647. Disponible en: https://doi.org/10.2307/3501371.

Derfler, L. (2009) [1998]. Paul Lafargue and the Flowering of the French Socialism, 1882-1911. Harvard: Harvard University Press.

Dobry, M. (coord.) (2003). Le mythe de l'allergie française au fascisme. París: Albin Michel.

Douglas, A. (1992). From fascism to libertarian communism. Georges Valois against the Third Republic. Berkeley y Los Angeles: University of California Press.

Drouin, J.-C. (1995). Georges Valois et les Cahiers des États Généraux (1923-1925). En G. Merlio (dir.). Ni gauche ni droite: les chassés-croisés idéologiques des intellectuels français et allemands dans l'entre-deux-guerres (pp. 103-121). Talance: Maison des Sciences de l'Homme d'Aquitaine.

Forti, S. (2014). El peso de la nación: Nicola Bombacci, Paul Marion y Óscar Pérez Solís en la Europa de entreguerras. Santiago de Compostela: Universidad de Santiago de Compostela.

Gallego, F. (1998). Ramiro Ledesma Ramos y el fascismo español. Madrid: Síntesis.

- (2014). El Evangelio fascista. La formación de la cultura política franquista (1930-1950). Barcelona: Crítica.

Giocanti, S. (2010) [2006]. Charles Maurras: el caos y el orden. Barcelona: Acantilado.

Girardet, R. (1955). Notes sur l'esprit d'un fascisme français. Revue française de science politique, 5 (3), 529-546. Disponible en: https://doi.org/10.3406/rfsp.1955.402622.

Grave, J. (1907). Bibliographie. Les Temps Nouveaux, 5.

(1973). Quarante ans de propagande anarchiste. París : Flammarion.

Gregor, J. A. (1979). Young Mussolini and the Intellectual Origins of Fascism. Berkeley y Los Ángeles: University of California Press.

Griffiths, R. (1966). The Reactionary Revolution. The Catholic revival in French literature, 1870/1914. Londres: Constable \& Company Ltd.

Guchet, Y. (1965). Georges Valois ou l'illusion fasciste. Revue française de science politique, 15 (6), 1111-1144. Disponible en: https://doi.org/10.3406/rfsp.1965.392901.

(2001) [1975]. Georges Valois. L'Action Française, Le Faisceau, La République Syndicale. París: L'Harmattan.

Gugelot, F. (1998). La Conversion des intellectuels au catholicisme en France, 1885-1935. París: CNRS Éditions.

Huguenin, F. (2013) [1998]. L'Action Française. Une histoire intellectuele. París: Perrin.

Jenkins, B. (ed.) (2007). France in the Era of Fascism: Essays on the French Authoritarian Right. Nueva York: Berghahn Books.

Julliard, J. (1989). Sur un fascisme imaginaire: à propos d'un livre de Zeev Sternhell. Annales. Économies, Sociétés, Civilisations, 39 (4), 849-861. 
Keegan, J. (2013) [1976]. El rostro de la batalla. Madrid: Turner Publicaciones S. L.

Levey, J. (1973). Georges Valois and the Faisceau: The Making and Breaking. French Historical Studies, 8 (2), 279-304. Disponible en: https://doi.org/10.2307/285928.

Linz, J. J. (1978) [1976]. Some notes to toward a comparative study of fascism sociological historical perspective. En W. Laqueur. Fascism. A reader's guide: analyses, interpretations, bibliography (pp. 3-127). Berkeley y Los Angeles: University of California Press.

Maurras, C. (1925a) [1900]. Enquête sur la monarchie. En C. Maurras. Enquête sur la monarchie. Suivie de Une campagne royaliste au "Figaro", et Si le coup de force est possible (pp. 33-463). París: Nouvelle Librairie Nationale.

— (1925b) [1900]. Une campagne royaliste au «Figaro». En C. Maurras. Enquête sur la monarchie. Suivie de Une campagne royaliste au "Figaro", et Si le coup de force est possible (pp. 467-536). París: Nouvelle Librairie Nationale.

— (1926) [1916]. De la liberté suïsse à l'unité française. En C. Maurras. Quand les Français ne s'aimaient pas. Chronique d'une renaissance, 1895-1905 (pp. 183-235). París: Nouvelle Librairie Nationale.

Mayeur, J.-M. (1984). La vie politique sous la Troisième République. París: Éditions du Seuil. McWilliam, N. (2010). Qui a peur de George Sand?: antiromantisme et antiféminisme chez les maurrassiens. En O. Dard, M. Leymarie y N. McWilliam (eds.). Le maurrassisme et la culture. L'Action Française: culture, société, politique (III) (pp. 173-185). Villeneuve d'Ascq: Presses Universitaires du Septentrion.

Milza, P. (1987). Fascisme français. Passé et présent. París: Flammarion.

Montusès, E. (1913). Le député en blouse. París: E. Figuière.

Navet, G. (1992). Le Cercle Proudhon (1911-1914). Entre le syndicalisme révolutionnaire et l'Action Française. Mil neuf cent. Revue d'histoire intellectuelle, 10, 46-63.

Nietzsche, F. (1995) [1887]. La genealogía de la moral (tratados I y II). Valencia: Servei de Publicacions de la Universitat de València.

Nolte, E. (1969) [1963]. Three faces of fascism. Nueva York: New American Library.

Ory, P. (1985). L'Anarchisme de droite ou du mépris considéré comme une morale, le tout assorti de réflexions plus générales. París: Bernard Grasset.

Pasetti, M. (2016). L'Europa corporativa. Una storia transnazionale tra le due guerre mondiali. Bolonia: Bolona University Press.

Prat, M. (1992). Georges Sorel et la décomposition du dreyfusisme. En M. Leymarie (dir.). La Posterité de l'Affaire Dreyfus (pp. 15-30). Villeneuve-d'Ascq: Presses Universitaires du Septentrion.

Prévotat, J. (2001). L’Action Française et les catholiques. Le tournant de 1908. Mil neuf cent. Revue d'histoire intellectuelle, 19, 119-126.

Prochasson, C. (1994) [1993]. Les années 1880: au temps du boulangisme. En M. Wincock (dir.). Histoire de l'extrême droite en France (pp. 51-82). París: Éditions du Seuil.

Prost, A. (2008). De l'enquête à la réforme. L'enseignement secondaire des garçons de 1898 à 1902. Histoire de l'éducation, 119, 29-80. Disponible en: https://doi.org/10.4000/histoire-education.1843.

Remond, R. (1963). La droite en France. De la première Restauration à la V République. París: Éditions Montaigne. 
Renard, P. (2003). L'Action Française et la vie littéraire (1931-1944). París: Presses Universitaires du Septentrion.

Richard, F. (1988). L'anarchisme de droite dans la littérature contemporaine. París: Presses Universitaires de France.

Roman, T. (2002). L'Indépendance. Une revue traditionaliste des années 1910. Mil neufcent. Revue d'histoire intellectuelle, 20, 173-193.

- (2003). L'Indépendance (1911 - 1913) et la crise de la bourgeoisie française. Mil neuf cent. Revue d'histoire intellectuelle, 17, 93-121.

Romano, S. (1981). Biografia e storiografia. Risorgimento, 1, 93-100.

Saint-Simon, H. de (1821). Du système industriel. París: Antoine-Augustin.

Salle, G. de la (1881). Prise d'armes. L'Art social, 1, 2-6.

Salsano, A. (1994). Georges Valois e lo Stato Tecnico. Il Corporativismo tecnocratico tra fascismo e antifascismo. Studi Storici, 34 (2/3), 571-624.

Schiano-Bennis, S. (1999). La renaissance de l'idéalisme à la fin du XIXe siècle. París: Honoré Champion.

Sérant, P. (1978). Les dissidents de l'Action française. Copernic.

Sorel, G. (1910) [1908]. Réflexions sur la violence. París: Marcel Rivière et C.

Soucy, R. (1989) [1986]. Le fascisme français. 1824-1933. París: Presses Universitaires de France.

— (1995). French Fascism: The Second Wave, 1933-1939. New Haven y Londres: Yale University Press.

Spiegel, G. M. (2006). La historia de la práctica: nuevas tendencias en historia tras el giro lingüístico. Ayer, 62 (2), 19-50.

Sternhell, Z. (1976). Anatomie d'un mouvement fasciste en France: le faisceau de Georges Valois. Revue française de science politique, 1, 5-40. Disponible en: https://doi. org/10.3406/rfsp.1976.393652.

— (1978). La droite révolutionnaire, 1885-1914. Origines françaises du fascisme. París: Éditions du Seuil.

- (1983). Ni droite ni gauche. L'idéologie fasciste en France. París: Éditions du Seuil.

- (1995). La troisième voie fasciste ou la recherche d'une culture politique alternative. En G. Merlio (dir.). Ni gauche ni droite: les chassés-croisés idéologiques des intellectuels français et allemands dans l'entre-deux-guerres (pp. 17-29). Talance: Maison des Sciences de l'Homme d'Aquitaine.

- Sznajder, M. y Asheri, M. (1994) [1989]. El nacimiento de la ideología fascista. Madrid: Siglo XXI Editores.

Taguieff, P.-A. (2007). Les contre-réactionnaires. Le progressisme entre illusion et imposture. París: Denoël.

Thibaudet, A. (1932). Les Idées politiques de la France. París: Stock, Delamain et Boutelleau.

Valla, J.-C. (2003). Georges Valois. De l'anarcho-syndicalisme au fascisme. París: Éditions de la Librairie Nationale.

Valois, G. (1906). L’homme qui vient: philosophie de l'autorité. París: Nouvelle Librairie Nationale.

- (1912). Pourquoi nous rattachons nos travaux à l'esprit proudhonien. Cahiers $d u$ Cercle Proudhon, 1, 29-33. 
(1913). Le Père: une philosophie de la famille. París: Nouvelle Librairie Nationale.

(1918a). Le Cheval de Troie. Réflexions sur la philosophie et sur la conduite de la guerre. París: Nouvelle Librairie Nationale.

- (1918b). La réforme économique et sociale : conférence faite au Cercle commercial et industriel de France le 10 octobre 1918. París: Nouvelle Librairie Nationale.

- (1919). L'économie Nouvelle. París: Nouvelle Librairie Nationale.

- (1920). La monnaie saine tuera la vie chère. París: Nouvelle Librairie Nationale.

— (1921). D’un siècle à l'autre. Chronique d'une génération (1885-1920). París: Nouvelle Librairie Nationale.

- (1922). L'État et la production. París: Nouvelle Librairie Nationale.

_ (1924a) [1909]. La monarchie et la classe ouvrière, dins d'Histoire et Philosophie sociales. París: Nouvelle Librairie Nationale.

- (1924b). La révolution nationale: philosophie de la victoire. París: Nouvelle Librairie Nationale.

- (1926). Contre le mensonge et la calomnie: les campagnes de l'Action Française. Mes réponses-mes accusations. París: Nouvelle Librairie Nationale.

- (1927a). Le fascisme. París: Nouvelle Librairie Nationale.

- (1927b). L'État syndical et la représentation corporative. Les semaines économiques et la campagne pour les États Généraux (1920-1924). París: Librairie Valois.

- (2012) [1928]. L'homme contre l'argent. Souvenirs de dix ans (1918 - 1928). Introducción de Dard, Olivier. Villeneuve d'Ascq: Presses Universitaires du Septentrion.

Vincent, G. (2004). Recherches sur la socialisation démocratique. Lión: Presses Universitaires de Lyon.

Weber, E. (1962). Action Française: Royalism and Reaction in Twentieh Century France. Stanford: Stanford University Press.

Winock, M. (1983). Fascisme à la française ou fascisme introuvable? Le Débat, 25, 35-44. Disponible en : https://doi.org/10.3917/deba.025.0035.

- (1993). Rochefort: la Commune contre Dreyfus. Mil neuf cent, 11 (11), 82-86. Disponible en: https://doi.org/10.3406/mcm.1993.1086.

- (2004) [1982]. Nationalisme, antisémitisme et fascisme en France. París: Éditions du Seuil.

- (2010). El siglo de los intelectuales. Buenos Aires: Edhasa.

Yonnet, F. (2004). Claude-Henri de Saint-Simon, l'industrialisme et les banquiers. Cahiers d'Économie Politique, 46, 147-174. Disponible en: https://doi.org/10.3917/cep.046.0147. 